\title{
INDUÇÃO DE PRÓFAGOS E RESISTÊNCIA A ANTIMICROBIANOS ENTRE GENÓTIPOS DE ESCHERICHIA COLI PRODUTORA DE TOXINAS SHIGA (STEC)
}

\author{
INDUCTION PROPHAGES AND RESISTANCE TO ANTIMICROBIAL IN SHIGA- \\ LIKE TOXIN-PRODUCING ESCHERICHIA COLI (STEC)
}

\author{
A. E. STELLA ${ }^{1 *}$, A. F. OLIVEIRA ${ }^{1}$, D. L. F. MENDONÇA ${ }^{1}$, L. ZAIDEN $^{1}$, B. SPIRA ${ }^{2}$
}

\begin{abstract}
RESUMO
Objetivos: A contagem de $\mathrm{PFU} / \mathrm{mL}$ indica a eficiência de produção de fagos pela indução dos prófagos, e geralmente corresponde à eficiência de expressão de genes localizados no lócus stx, bem como a expressão dos promotores stx 1 e stx 2 nos fagos-stx é diferentemente regulada. Em geral fagos lisogênicos tem particular importância para a dinâmica populacional das células hospedeiras como as STEC. Eles podem aumentar a aptidão competitiva da bactéria hospedeira devido a sua capacidade de alternar para o ciclo lítico e destruir bactérias rivais. Material e Método: Os isolados STEC $(\mathrm{n}=67)$ foram cultivados e após uma alíquota foi coletada e centrifugada, em seguida foi adicionado $50 \mu 1$ de clorofórmio. Foram feitas diluições seriadas do sobrenadante e plaqueadas com Top agar e a bactéria receptora E. coli C600. A contagem das unidades formadoras de placas de lise (PFU) foi realizada após a incubação há $37^{\circ} \mathrm{C}$ por 24 horas. Os testes de resistência aos antimicrobianos foram realizados usando-se a técnica de discodifusão. Resultados: Foram observadas as seguintes frequências de resistência (sulfametoxazol + trimetoprim $1.49 \%$; ciprofloxacina $0 \%$; cefalotina $40.29 \%$; cefoxitina $0 \%$; tetraciclina $0 \%$; ertapenem $1.49 \%$; amicacina $2.98 \%$; gentamicina $1.49 \%$; amoxicilina+clavulanato $0 \%$; norfloxacin $0 \%$ e ampicilina $0 \%$ ). Nota-se também que a disseminação da resistência a cefalotina independe da produção ou não de fagos, pois seus níveis de resistência se mostraram próximos, 39.39\% em cepas que não produziram fagos e $41.17 \%$ em cepas onde observou-se a sua produção, isto pode ser naturalmente explicado pelo local de ação deste antibiótico, a parede celular, pois a Escherichia coli é menos sensível aos antibióticos betalactâmicos(cefalotina) uma vez que sua parede de peptideoglicanas é mais delgada e esta protegida pela membrana celular lipofílica externa. Conclusão: Não foram observados isolados multirresistentes entre as STEC analisadas. Também não foram observadas correlações positivas entre a quantidade de fagos produzidos e a resistência aos antimicroabianos.
\end{abstract}

PALAVRAS-CHAVE: RESISTÊNCIA. BACTERIÓFAGOS. TOXINA SHIGA.

AGRADECIMENTOS: FAPESP

ÁREA TEMÁTICA: Doenças Infecciosas 